\title{
Effective Sunspot Numbers, January 1961 through July 1962
}

\author{
W. B. Chadwick
}

\section{Contribution from the Central Radio Propagation Laboratory, National Bureau of Standards, Boulder, Colo.}

(Received June 15, 1962)

\begin{abstract}
It is proposed that the estimated smoothed annual sunspot number obtained by the method of a previous paper [Chadwick, 1961] be termed effective sunspot number. The series of such numbers is continued through July 1962.
\end{abstract}

In a previous paper [Chadwick, 1961] the author derived regression equations for each month of the year, by means of which, upon substituting a value for $f$ (defined as the diurnal maximum of monthly median $f_{0} F_{2}$ in megacycles per second, i.e., the highest value from among the 24 hourly medians for a given month) values of $R_{z}$ (12-month running average Zürich sunspot number) could be estimated. Values of $R$ (est) using $f_{0} F_{2}$ data from Washington, D.C., were presented. Sample results for Fairbanks, Alaska, Christchurch, N.Z., and Huancayo, Peru, were shown for purposes of comparison.

Since the values of $R$ (est) were found using a parameter of the ionosphere, it is suggested that the term "effective sunspot number" $R$ (eff) be used for the estimated numbers so obtained.

Experience with this method over the past year strengthens the tentative conclusion of the previous paper that a minimum of two locations should be used, one in each hemisphere, each station to cover its own winter months. Thus table 1 represents an expansion of table 6 of the previous paper, to include results for Christchurch for the months April through September.
Table 2 expands table 5 of the referenced article. By comparing $R$ (eff) at Washington and Christchurch with $R_{z}$ (smoothed 12 -month running average Zürich sunspot number) for the corresponding months, it is seen that the Christchurch equations give what is probably a better index value for the months June 1961 through September 1961.

The low values of $R$ (eff) (Washington) during the 1961-1962 winter months and the higher values beginning with March 1962 coincide with a period of difficulty because of reduction in $\mathrm{HF}$ usable frequency bands, followed by a recovery period, as informally reported by practical HF communicators.

Finally, the point should be stressed that this method is indeed a quick one, and that presumably the statistics could be improved by more elaborate procedures. If estimates are based on data limited to one location, something abnormal may render the index suspect for a period of time. As an example, the diurnal curves of median $f_{0} F_{2}$ for Washington, June through August 1961, showed an unexpectedly large increase in the late afternoon hours, much larger than the rise normal for these months at these hours, as experienced during the previous 20 years. A similar effect occurred in May and June 1962.

TABLE 1. Correlation coefficients, regression equations, standard errors, values of $\mathrm{f}$, effective values of $\mathrm{R}$, for Christchurch, New Zealand, 1945 to 1960

\begin{tabular}{|c|c|c|c|c|c|c|c|}
\hline Christchureh & $\begin{array}{l}\text { Corr. } \\
\text { coeff. }\end{array}$ & Regression equations & $\begin{array}{l}\text { Stand- } \\
\text { ard } \\
\text { errors b }\end{array}$ & $\begin{array}{c}1961 \\
f(\mathrm{Mc} / \mathrm{s})\end{array}$ & $\begin{array}{c}1961 \\
R(\mathrm{eff})\end{array}$ & $\begin{array}{c}1962 \\
f(\mathrm{Mc} / \mathrm{s})\end{array}$ & $\begin{array}{c}1962 \\
R(\text { eff })\end{array}$ \\
\hline $\begin{array}{l}\text { Jan } \\
\text { Apr } \\
\text { May } \\
\text { June } \\
\text { July } \\
\text { Aug } \\
\text { Sept }\end{array}$ & $\begin{array}{r}0.94 \\
0.96 \\
\text { a } 0.97 \\
\text { a } 0.96 \\
\text { a } 0.96 \\
\text { a } 0.96 \\
0.94\end{array}$ & $\begin{array}{ll} & R=96.0+48.7(f-7.7) \\
& R=97.6+19.9(f-10.4) \\
\text { a } & R=102.5+19.7(f-10.0) \\
\text { a } & R=102.5+22.0(f-9.2) \\
\text { a } & R=102.4+22.8(f-8.9) \\
\text { a } & R=102.3+23.3(f-8.8) \\
& R=98.8+22.6(f-8.7)\end{array}$ & $\begin{array}{r}22.2 \\
18.2 \\
\text { a } 16.7 \\
\text { a } 18.9 \\
\text { a } 18.9 \\
\text { a } 17.9 \\
22.2\end{array}$ & $\begin{array}{l}7.4 \\
9.3 \\
7.3 \\
7.0 \\
7.0 \\
7.4 \\
7.0\end{array}$ & $\begin{array}{l}81.4 \\
75.7 \\
49.3 \\
54.1 \\
59.1 \\
69.7 \\
60.4\end{array}$ & $\begin{array}{l}7.0 \\
8.0 \\
7.0 \\
6.6 \\
6.0\end{array}$ & $\begin{array}{l}61.9 \\
49.8 \\
43.4 \\
45.3 \\
36.3\end{array}$ \\
\hline
\end{tabular}

a 15 years; data missing for 1955

b Standard error of an estimated $R$ for mean $f$. 
TABLE 2. Values of $\mathrm{f}$ at Washington, effective values of $\mathrm{R}$, predicted values of $\mathrm{R}$ by McNish-Lincoln method, values of $12-m o n t h$ running average $\mathrm{R}_{\mathrm{z}}$, Jan. 1961-July 1962

\begin{tabular}{|c|c|c|c|c|c|c|c|c|}
\hline & \multicolumn{4}{|c|}{1961} & \multicolumn{4}{|c|}{1962} \\
\hline & $f(\mathrm{Mc} / \mathrm{s})$ & $R(\mathrm{eff})$ & $\begin{array}{l}R \text { (Pred., } \\
\text { McN-L) }\end{array}$ & $R_{z}$ & $f(\mathrm{Mc} / \mathrm{s})$ & $R(\mathrm{eff})$ & $\begin{array}{l}R \text { (Pred., } \\
\text { McN-L) }\end{array}$ & $R_{z}$ \\
\hline $\begin{array}{l}\text { Jan } \\
\text { Feb } \\
\text { Mar } \\
\text { Apr } \\
\text { May } \\
\text { June } \\
\text { July } \\
\text { Aug } \\
\text { Sept } \\
\text { Oct } \\
\text { Nov } \\
\text { Dec }\end{array}$ & $\begin{array}{l}9.2 \\
8.6 \\
8.6 \\
7.4 \\
6.8 \\
6.9 \\
6.8 \\
7.2 \\
7.8 \\
8.6 \\
8.2 \\
7.6\end{array}$ & $\begin{array}{r}75.0 \\
59.4 \\
67.1 \\
59.5 \\
59.5 \\
85.1 \\
101.2 \\
97.6 \\
72.0 \\
51.4 \\
40.1 \\
30.8\end{array}$ & $\begin{array}{l}97.4 \\
93.8 \\
90.2 \\
88.5 \\
86.2 \\
84.1 \\
78.9 \\
75.2 \\
71.4 \\
68.1 \\
63.9 \\
60.1\end{array}$ & $\begin{array}{r}80.2 \\
74.8 \\
68.8 \\
64.3 \\
60.1 \\
55.8 \\
\text { b } 53.0 \\
52.3 \\
51.9 \\
50.9 \\
49.8 \\
48.0\end{array}$ & $\begin{array}{l}7.2 \\
7.6 \\
8.0 \\
7.0 \\
7.1 \\
6.7 \\
6.0\end{array}$ & $\begin{array}{r}34.0 \\
40.4 \\
55.8 \\
49.9 \\
71.3 \\
73.9 \\
58.4\end{array}$ & $\begin{array}{l}57.3 \\
52.8 \\
48.0 \\
44.6 \\
40.8 \\
37.4 \\
35.1\end{array}$ & 44.4 \\
\hline
\end{tabular}

a From col. D, table 2 of Reference; all others from col. E.

b Provisional values beginning with July 1961 .

Thus $R$ (eff) based on Washington data appears to be much too high in these months. Nevertheless, it is believed that this method of estimating the stage of the sunspot cycle, because of its simplicity, is of considerable value, and that it can help to identify periods when the effect of solar activity on practical HF communications may depart considerably from that expected when using the usual 12-month running-average type of index. As an instance of its use during the past few months, the extremely rapid decline of the current cycle (1960 yearly Zürich number, 112; 1961 yearly number, 54) led some observers to believe that this cycle might be as short as 8 years. But the recovery of the effective number to 56 in March 1962 indicated that it might still be several years to minimum.

\section{Reference}

Chadwick, W. B., A quick method for estimating the stage of the sunspot cycle, J. Research NBS 65D (Radio Prop.) No. 6, 637-640 (Nov.-Dec. 1961).

(Paper 67D1-241) 